\title{
Awareness and Perception Regarding Corona Virus Disease 19 Outbreak among General Public of Selected Area of Kathmandu
}

\author{
Kiran Chhetri $^{1}$, Puspa Kumari Deo ${ }^{2}$ \\ ${ }^{1}$ Nursing Instructor, Vinayak College of Health Science, Kathmandu, Nepal \\ ${ }^{2}$ Lecturer, Assistant Head of Department, Nobel College, Sinamangal, Kathmandu, Nepal \\ Corresponding Author: Kiran Chhetri
}

\begin{abstract}
Background: Coronavirus disease 2019 is an upcoming contagious respiratory infection caused by a new coronavirus named severe acute respiratory syndrome (SARS-CoV2) which is transmitted through the respiratory droplets produced by coughing or sneezing of an infected person. The behavior of the general public will probably have an important bearing on the course of coronavirus disease 2019 (COVID-19) epidemic. Human behavior is influenced by knowledge and perceptions. This paper aims to identify the awareness and perception regarding COVID-19 among general public.

Method: A cross sectional descriptive design was used by using structured online questionnaire through Google form. The study was conducted at certain area of Kathmandu. Sample size was 423 with non probability convenience sampling technique.

Result: The findings revealed that overall, $44.9 \%$ respondents had low, $34.0 \%$ had average and $21 \%$ had high level of awareness. Likewise, $56.6 \%$ had positive perception and $43.2 \%$ had negative perception about COVID outbreak. Also 62\% respondents had positive and $37.7 \%$ had negative perception about prevention of COVID. There is an association between educational status and level of awareness with 'p' value lesser than 0.05 at $95 \%$ level of confidence.

Conclusion: Majority of respondents were not aware about the outbreak of COVID19. Also more than half of respondents had positive perception about outbreak of COVID 19. The effective measures are being taken by the government and the public, still there remains a need for further awareness campaigns and knowledge of safe interventions to combat the spread of disease.
\end{abstract}

Keywords: awareness, perception, COVID19, general public

\section{INTRODUCTION}

Corona Virus Disease emerged in Wuhan, China at the end of 2019. Since then, it has spread to 200 countries and had been declared a global pandemic by World Health Organisation. To date, there are more than 2.3 million positive COVID-19 cases recorded with at least 150,000 deaths globally. ${ }^{[1]}$

The COVID-19 is caused by novel corona virus, which is transmitted through the respiratory droplets produced as a result of coughing or sneezing of a COVID-19 infected person. Wash your hands frequently, maintain social distance of one meter, follow good respiratory hygiene are some of the preventive measures we can take against this pandemic. ${ }^{[2]}$

On 24 March 2020 government imposed a complete lockdown in Nepal including business and college closures and restrictions on movement within the country and flight access in and out. Discussion is ongoing to enable the movement of those supporting preparedness and response to the current situation. ${ }^{[3]}$ 


\section{METHOD}

\section{Selection and description of participants}

The population of this study were adult of age above 18 . The sample size for this study was 423. The study was conducted at a municipality in Kathmandu District in the province no 3 of Nepal. Informed consent was obtained from all the respondents in the study. Respondent's privacy, anonymity and confidentiality were fully maintained.

\section{Technical information}

The objective of this study was to assess the awareness and perception of general public regarding COVID 19. Cross sectional descriptive design was used to assess the awareness and perception regarding COVID 19. Non probability convenience sampling technique was used to collect the data. A structured self administered English version questionnaire was developed into a digital form (Google form) that was developed by reviewing the relevant literature and consulting experts. The questionnaire was divided into four parts. First part was about the respondent's biodemographic data, second part regarding awareness about COVID likewise the third part was concerned about perception about COVID. The questions were pre tested and took about 10-15 minutes to complete.

\section{Statistical analysis}

The received responses, in Google form, were exported to Microsoft Excel and then imported into IBM Statistical Package for Social Sciences (SPSS) Statistics for windows Version 20 for data analysis. Descriptive statistics such as frequency and percentage described respondents' demographic characteristics. In inferential statistics used fisher's exact test to find out the association between awareness level and selected demographic variables. Awareness score 0 to $39 \%$ was considered as low awareness, 40-69\% was considered as average level of awareness and 70\% and above was considered as high level of awareness. ${ }^{[4]}$ The total score was calculated.
Likert scale was used to obtain perception of the respondents where a type of psychometric scale was used in which responders specify their level of agreement to a statement typically in five points which are (1) Strongly agree (2) agree (3) neutral (4) disagree (5) Strongly disagree. And for association of awareness level with a variable, Fisher's exact test was used. The data were presented in tabular form.

\section{Ethical consideration}

The Institutional Review Committee at Nobel College, Sinamangal affiliated under Pokhara University, Nepal, approved this study. And the tool was developed by consulting experts. The link was circulated through the viber and messenger. The first page of the survey had an informed consent page that provided details of the study and required respondents to participate (or decline) the survey. Participation in the survey was voluntary, and no incentive was provided to respondents. Respondents' rights were respected by obtaining informed consent, maintaining confidentiality, anonymity and privacy, as well as showing respect for the dignity of respondents.

\section{RESULTS}

Table 1: Respondent's age, gender, ethnicity and religion, $\mathrm{n}=\mathbf{4 2 3}$

\begin{tabular}{|l|c|c|}
\hline Sociodemographic data & Frequency & Percentage \\
\hline Age & & \\
\hline $18-25 y r s$ & 232 & 54.8 \\
\hline $26-35 y r s$ & 173 & 40.9 \\
\hline 36-45yrs & 17 & 4.0 \\
\hline 46yrs and above & 1 & 0.2 \\
\hline Gender & & \\
\hline Male & 215 & 50.8 \\
\hline Female & 208 & 49.2 \\
\hline Ethnicity & & \\
\hline Brahmin & 94 & 22.2 \\
\hline Chhetri & 226 & 53.4 \\
\hline Newar & 94 & 22.2 \\
\hline Others & 9 & 2.1 \\
\hline Religion & & \\
\hline Hindu & 357 & 84.4 \\
\hline Buddist & 26 & 6.1 \\
\hline Christian & 22 & 5.2 \\
\hline Muslim & 11 & 2.6 \\
\hline Others & 7 & 1.7 \\
\hline
\end{tabular}

Table 1 revealed the distribution of respondents according to demographic data whereas out of total respondents, 
Kiran Chhetri et.al. Awareness and perception regarding Corona Virus Disease 19 outbreak among general public of selected area of Kathmandu.

$232(54.8 \%)$ were of $18-25$ years, $173(40.9 \%)$ were of $26-35$ years, $17(4.0 \%)$ were of $36-45$ years and $1(0.2 \%)$ was of 46 years and above. 215(50.8\%) were male and 208(49.2\%) were female. 94(22.2\%) were Brahmin, 226(53.4\%) were Chhetri, 94(22.2\%) Newar and 9(2.1\%) others, also $357(84.4 \%)$ belong to Hindu religion, 26(6.1\%) Buddhist, 22(5.2\%) Christian and $11(2.6 \%)$ were Muslim.

Table 2: respondent's educational status, occupation, marital status and monthly income, $n=423$

\begin{tabular}{|l|l|l|}
\hline Sociodemographic data & Frequency & Percentage \\
\hline Educational status & & \\
\hline SEE passed & 57 & 13.5 \\
\hline+2 or intermediate level & 117 & 27.7 \\
\hline Bachelor & 199 & 47.0 \\
\hline masters and above & 50 & 11.8 \\
\hline Occupation & & \\
\hline Student & 276 & 65.2 \\
\hline health care provider & 49 & 11.6 \\
\hline home maker & 4 & 0.9 \\
\hline Service & 33 & 7.8 \\
\hline Business & 60 & 14.2 \\
\hline Others & 1 & 0.2 \\
\hline marital status & & \\
\hline Married & 249 & 58.9 \\
\hline Unmarried & 174 & 41.1 \\
\hline monthly income & & \\
\hline$<10,000$ rupee & 19 & 4.5 \\
\hline $11-20,000$ rupee & 21 & 5.0 \\
\hline $21-30,000$ rupees & 74 & 17.5 \\
\hline $31,000-40,000$ rupees & 91 & 21.5 \\
\hline more than 40000 & 218 & 51.5 \\
\hline & & \\
\hline
\end{tabular}

Table 2 revealed the distribution of respondents according to demographic data where out of total respondents, 57(13.5\%) were SEE passed, 117(27.7\%) were +2 passed, 199(47\%) were educated to bachelor level, and $50(11.8 \%)$ were educated to masters and above. Also 276 (65.2\%) were students, $49(11.6 \%)$ were health care providers, $4(0.9 \%)$ were homemakers, $33(7.8 \%)$ were in service and 60(14.2\%) were businessperson. $24(58.9 \%)$ of the respondents were married and 174(41.15) were unmarried. 91(21.5\%) respondents had an income of 31,000-40,000 rupees and $218(51.5 \%)$ had monthly income more than Rs 40,000 .

Table 3: overall awareness level of respondents regarding outbreak of COVID $-19, n=423$

\begin{tabular}{|l|l|l|}
\hline level of awareness & Frequency & percent \\
\hline low awareness & 190 & 44.9 \\
\hline average awareness & 144 & 34.0 \\
\hline high awareness & 89 & 21 \\
\hline
\end{tabular}

Table 3 revealed the awareness level of respondents whereas out of all the respondents, 190(44.9\%) had low awareness level, 144(34.0\%) had average awareness level and $89(21 \%)$ had high awareness level. The awareness level was adopted from Thakrar R (2014)et al. ${ }^{[4]}$

Table 4: perception of respondents about outbreak of covid 19, $\mathrm{n}=423$

\begin{tabular}{|l|l|l|}
\hline perception about COVID 19 break & Frequency & Percent \\
\hline positive perception & 240 & 56.6 \\
\hline negative perception & 183 & 43.2 \\
\hline
\end{tabular}

Table 4 revealed the perception of respondents about outbreak of covid 19 whereas out of all the respondents, $240(56.6 \%)$ had positive perception about covid outbreak and $183(43.2 \%)$ had negative perception about covid outbreak.

Table 5: perception of respondents about prevention of covid 19, $n=423$

\begin{tabular}{|lll|l|l|}
\hline Perception about prevention of & Frequency & Percent
\end{tabular}

\begin{tabular}{|l|l|l|}
\hline COVID 19 & & \\
\hline positive perception & 263 & 62 \\
\hline negative perception & 160 & 37.7 \\
\hline
\end{tabular}

Table 5 revealed the perception of respondents about prevention of covid 19 where out of all respondents 263(62\%) respondents had positive perception and $160(37.7 \%)$ had negative perception regarding prevention of covid 19.

Table 6: Association between selected sociodemographic variables and level of awareness, $n=423$

\begin{tabular}{|c|c|c|c|c|c|}
\hline & & \multicolumn{3}{|l|}{ Awareness level } & \multirow[t]{2}{*}{ p value } \\
\hline & & Low awareness & average awareness & High awareness & \\
\hline \multirow[b]{4}{*}{ Age group } & $18-25$ & 109 & 74 & 49 & \multirow[t]{4}{*}{0.117} \\
\hline & $26-35$ & 76 & 58 & 39 & \\
\hline & $36-45$ & 5 & 11 & 1 & \\
\hline & 46 and above & 0 & 1 & 0 & \\
\hline \multirow{4}{*}{ Education status } & SEE passed & 8 & 28 & 21 & \multirow[t]{4}{*}{0.012} \\
\hline & +2 or intermediate level & 62 & 35 & 20 & \\
\hline & Bachelor & 116 & 47 & 36 & \\
\hline & masters and above & 4 & 34 & 12 & \\
\hline
\end{tabular}


Table 6 showed that there was no association between age and awareness level where the " $p$ " value was greater than 0.05 at $95 \%$ level of confidence also there was an association between education and awareness level where the " $p$ " value was lesser than 0.05 at $95 \%$ level of confidence.

\section{DISCUSSION}

This study is intended to assess the awareness and perception regarding COVID 19 outbreak in a certain area of Kathmandu. A total of 423 respondents were undertaken in this study.

According to the findings, $79.9 \%$ had given correct answer for COVID 19 as infectious respiratory disease caused by novel corona virus. This finding was similar to the study done among Nepali residents where the rates for correct answer for COVID-19 knowledge questionnaire ranged from $60-98.7 \%$. ${ }^{[4]}$

In concern to the incubation period, $59.6 \%$ had given correct answer for incubation period of COVID 19. This finding contradicts to the study done among Indian academicians and students where $91.8 \%$ knew about the incubation period of Covid19. ${ }^{[5]}$

Regarding awareness level, respondents with bachelor degree have more awareness than respondents who are SLC passed, +2 or intermediate level and masters and above. This finding contradicts with the study done among general public of Tamil Naidu where the people who hold post graduate and above have more awareness, than the people having school education only. [4]

Majority of the respondents $78.7 \%$ respondents uses mask while going outside and also cover both mouth and nose with the mask. This finding was similar to a study done among Nepali residents where $92.4 \%$ participants wore masks while going out which significantly differed across gender. [6]

In response to the study, $62.2 \%$ of the respondents had positive perception about the prevention and control of COVID
19. This finding was similar to a study done among residents where $87 \%$ of them were positive that COVID 19 could be controlled. [7]

\section{CONCLUSION}

Based on the findings, it was concluded that majority of respondents were not aware about the outbreak of COVID 19. And regarding perception, more than a half of respondents had positive perception about outbreak of COVID 19 and majority of them had positive perception about prevention of COVID 19. Also there was an association between education status and awareness level of participants. On its implication, this study can help assess the total awareness regarding COVID 19 among general public so that further activities regarding prevention can be carried out. Also this study can help the local policy makers for planning their further steps in preventing transmission of COVID 19.

\section{Conflict of Interest}

The authors declared that there are no conflicts of interest.

\section{Authors' Contribution}

Kiran Chhetri carried out the design of the study, the paper's conception, data collection, analysis, and interpretation of data and drafted the paper. Puspa Kumari Deo participated in the design of the study, data analysis, and interpretation of data and review of the paper. Authors are participated in editing and approved the final manuscript.

\section{ACKNOWLEDGEMENTS}

The authors' great gratitude goes to Nobel College Sinamangal, Kathmandu affiliated to Pokhara University for ethical approval. Finally, the authors' heartfelt thanks go to all the participants.

\section{Source of Funding: None}

Ethical Approval: Approved 
Kiran Chhetri et.al. Awareness and perception regarding Corona Virus Disease 19 outbreak among general public of selected area of Kathmandu.

\section{REFERENCES}

1. Coronavirus disease 2019 (COVID-19): Situation report- 91. WHO[Internet];2020Jan 29. Available from: https://www.who.int/docs/defaultsource/coronaviruse/situationreports/20200420-sitrep-91-covid19.pdf?sfvrsn=fcf0670b_4

2. Anju KJ , Arulsamy S. The awareness of covid 19 among the prople of Tamil Naidu. Mukt Shabd Journal.2020 June 11; Issn No : 2347-3150. Available from: https://dx.doi.org/10.3390\%2Fijerph171971 77

3. COVID 19 Nepal: preparedness and response plan(NPRP),Ministry of Health and population; April 14, 2020.56p report no:1. Available from : https://www.who.int/docs/defaultsource/nepal-documents/novelcoronavirus/covid-19-nepal-preparednessand-response-plan-(nprp)

4. Thakrar, R., Alaparthi, G. K., Kumar, S. K. K., Vaishali, K., Zulfeequer, C. P. \& Aanad, R. Awareness in patients with COPD about the disease and pulmonary rehabilitation: A survey. Lung India.2014 April - June ; 31 (12), 134 - 138. DOI:10.4103/09702113.129837.Available from : https://www.researchgate.net/publication/26 1957009_Awareness_in_patients_with_CO PD_about_the_disease_and_pulmonary_reh abilitation_A_survey

5. Hussain A, Garima T, Singh B, Ram R, Tripti R. Knowledge, attitudes, and practices towards COVID-19 among
Nepalese Residents: A quick online crosssectional survey. Asian Journal of Medical Sciences.2020; 11(3), 6-11. Available from: https://doi.org/10.3126/ajms.v11i3.28485

6. Ranjith M.Awareness about Covid-19 A Study on Indian Academicians and Students: HealthcareReview.2020; 1(1),243 5.Availablefrom:https://sriopenjournals.com /index.php/healthcare_review/article/view/1 2

7. Poudel S, Shrestha S, Karmacharya I, Pathak K. Knowledge, attitude, and practices (KAP) towards COVID-19 among Nepalese residents during the COVID-19 outbreak: An online cross-sectional study. Research Square. 2020;09(3) [google scholar]. DOI:10.21203/rs.3.rs-31044/v1 Available from: https://www.researchsquare.com/article/rs31044/v1

8. Hamza MS, Badary OA, Elmazar MM. Cross-Sectional Study on Awareness and Knowledge of COVID-19 Among Senior pharmacy Students. J Community Health. 2020 Jun 15;1-8. Epub ahead of print. PMID:32542552; PMCID: PMC7295146. Available from:https://doi: 10.1007/s10900-020-00859-z.

How to cite this article: Chhetri K, Deo PK. Awareness and perception regarding Corona Virus Disease 19 outbreak among general public of selected area of Kathmandu. Int J Health Sci Res. 2021; 11(10): 67-71. DOI: https://doi.org/ 10.52403/ijhsr.20211010 